First Peoples Child \& Family Review

An Interdisciplinary Journal Honouring the Voices, Perspectives, and Knowledges of First Peoples through Research, Critical Analyses, Stories, Standpoints and Media Reviews

\title{
The New Way Forward
}

\section{Robert Joseph}

Volume 9, numéro 2, 2014

Respect and Equity Through Reconciliation : special Edition by Children and Youth

URI : https://id.erudit.org/iderudit/1077944ar

DOI : https://doi.org/10.7202/1077944ar

Aller au sommaire du numéro

Éditeur(s)

First Nations Child and Family Caring Society of Canada

ISSN

1708-489X (imprimé)

2293-6610 (numérique)

Découvrir la revue

Citer ce document

Joseph, R. (2014). The New Way Forward. First Peoples Child \& Family Review, 9(2), 5-5. https://doi.org/10.7202/1077944ar d'utilisation que vous pouvez consulter en ligne.

https://apropos.erudit.org/fr/usagers/politique-dutilisation/ 


\section{Editorials}

\section{The New Way Forward}

\section{Chief Dr. Robert J oseph ${ }^{1}$}

I am a Kwakwaka'wakw person from the coast of British Columbia. Our group lives on the North Vancouver Island area of Vancouver and onto the mainland and we have a really ancient culture that has thrived there for thousands of years. And we still exercise and carry and practise some of the traditions that are important to us, including how we perceive children in our world and practices and perspectives around child-raising.

I think that one of the greatest tragedies of all of the little children who went to Residential Schools was that we never experienced love, it was just simply absent in our lives and it resonated in my life for a long time. In spite of all of those things that were broken and the things that we were not able to do for our children anymore, we still deeply love them, we still deeply desire to re-empower ourselves to raise our children in a way that we want to.

As Canadians, we share a responsibility to look after each other and to acknowledge the pain and suffering that our diverse societies have endured, a pain that has been handed down to the next generations. We need to right these wrongs, heal together and create a new future that honours the unique gifts of our children and grandchildren. I have been working in Vancouver, B.C., across the country talking about Canadians and talking about Aboriginal peoples and talking to all kinds of ethnic groups about who we are as Canadians. And everybody - in the boardrooms in Vancouver, British Columbia, the big wheel CEOs, the politicians, the ordinary people, the people who are public servants - agrees that this is the time that we ought to be starting this new discourse of who we are and start to talk about a new relationship between all of us that is different than anything we have had before this moment.

I think we can find a new way forward that is going to hold promise for every Canadian child born - that every kid can achieve their optimum potential. That is the dream and we can make it happen.

1 Watch Chief Dr. Robert J oseph's testimony at: http:// aptn.ca/ news/ tag/ kids-in-care 